\title{
MRD evaluation, targeted therapy and stem cell transplantation: how to combine in adult ALL
}

\section{Dieter Hoelzer}

J. W. Goethe University, Frankfurt

Professor Dr D Hoelzer,

Department of Internal Medicine II, Hematology and

Oncology, Goethe University Hospital, ONKOLOGIKUM,
Frankfurt am Museumsufer, Schaubstr. 16, 60596 Frankfurt, Germany.

E-mail: Hoelzer@em.uni-frankfurt.de

\section{Summary}

There exist standard molecular methods of minimal residual disease (MRD) evaluation in acute lymphoblastic leukemia (ALL), in order to detect leukemic blast cells (LBC) not assessable by microscopy of bone marrow. The best time point for MRD evaluation and MRD-based treatment stratification in ALL is shown to be ca.14-16 weeks after induction/ consolidation treatment. Reduction of MRD load before SCT, as a next step of therapy, is quite desirable. E.g., induction and consolidation treatment with tyrosine kinase inhibitors (NKI) increase the molecular CR rate compared to conventional chemotherapy, as measured by the quantitative RT-PCR assays of $\mathrm{bcr} / \mathrm{abl}$ fusion oncogene. Failure of treatment by molecular criteria identifies the worst ALL subgroup. Several window studies in ALL with new cytostatic drugs (TKIs or MoABs) were aimed to reduce the tumor load before SCT. Moreover, novel immunotherapeutic approaches include application of monoclonal antibodies against specific surface antigens typical to certain differentiation steps in B-lineage.

Hence, evaluation of minimal residual disease is a new parameter for treatment stratification. The conversion of MRD-positivity to MRD-negativity is also a new endpoint for studies. Targeted therapy with TKI has improved the outcome for adult Ph+ ALL patients substantially, evidently by an increased molecular remission rate, and a substantial improvement of survival after SCT. Meanwhile, maintenance with a TKI is recommended after SCT, whereby the optimal duration is so far not known. Maintenance with a TKI is recommended after SCT, whereby the optimal duration is so far not known.

\section{Keywords}

acute lymphoblastic leukemia, minimal residual disease, tyrosine kinase inhibitors, monoclonal antibodies, molecular remission, clinical outcomes.

\section{Introduction}

Progress in adult acute lymphoblastic leukemia (ALL) in recent years is based on new diagnostic procedures, particularly the evaluation of Minimal Residual Disease (MRD), and detection of novel genetic aberrations.

At the therapeutic site the instrumentarium has been extended with targeted therapy; either with tyrosine kinase inhibitors (TKI) in $\mathrm{Ph} / \mathrm{bcr}$-abl+ ALL or, more recently, with immunotherapeutic approaches [7].

\section{Minimal Residual Disease}

There exist standard methods and definitions of MRD in ALL, in order to detect leukemic blast cells (LBC) not assessable by microscopic examination of bone marrow. Therefore, molecular complete remission (MolCR) is defined as $\leq 0,01 \%$ $=\leq 1 \mathrm{LBC}$ in 10.000 normal cells. The molecular methods include flow cytometry (FC), or molecular biology (nucleic acid-based) approaches. Appropriate sensitivity thresholds are: $10^{-3}-10^{-4}$ for FC, and $10^{-5}$, for RT PCR (e.g., bcr/abl detection) [4]. Clonal gene rearrangements of immunoglobulin heavy 
chain $(\operatorname{IgH})$ or T-cell receptor (TCR- $\beta, \delta, \gamma)$ are as sensitive as $10^{-4}$. In sum, the quantitative MDR biomarkers are applicable in $>90 \%$ of ALL cases.

The best time point for MRD evaluation and MRD-based treatment stratification is shown to be ca. $14-16$ weeks after induction/consolidation treatment, according to the most studies. A molecular response by the week 16 after Consolidation I is most informative, with highest molecular CR rates, in order to predict outcomes of CR in standard-risk (Ph-negative) ALL, according to the GMALL Studies (06/9907/03).

Failure of treatment by molecular criteria identifies now the worst ALL subgroup. In cases of MRD-positivity after induction/consolidation, stem cell transplantation (SCT) is considered as an option which provides sufficient increase in disease-free survival in adult ALL (standard and high risk groups) [1]. Preparation for SCT requires fast donor search, reserving place for potential haplo-, or cord blood SCT. Reduction of MRD load before SCT is quite desirable.

\section{Pre-SCT tumor load reduction: window studies}

Reduction of MRD load before SCT is quite desirable. What approaches should be considered when treating patients positive for MRD before SCT? The so-called window studies with new cytostatic drugs (TKIs or MoABs) are aimed to reduce the tumor load before SCT. These studies allow to explore clinical effects of new drugs, measured quantitatively by MRD levels. One of those window studies was done with Nelarabine (Atriance/ Arranon), a T cell-specific drug, in relapsed/refractory T-ALL/T-LBL [5]. In this study, the CR rate was $>40 \%$, but the rate of MRD-negativity was even higher, thus allowing more MRD-negative patients to receive a transplant. Also, TKI as well as immunotherapeutic approaches have been explored in this situation.

Overall, window studies in ALL seem to be the best place for exploring new drugs. According to regulations from authorities, the novel drugs are initially explored in refractory/relapsing ALL, but it seems that some of the new drugs should be preferentially tested in the MRD-positive situation, since they might be more active if a patient has only a smaller tumor load.

The question whether it is useful to reduce the tumor load before SCT arises particularly in Ph+ ALL. It could be demonstrated in several studies that the TKI treatment during induction and consolidation increases the molecular CR rate measured by the quantitative RT-PCR bcr-abl assay to $50-70 \%$, as compared to only $5 \%$ with chemotherapy [2]. However, it is not quite clear in $\mathrm{Ph} / \mathrm{bcr}-\mathrm{abl}+\mathrm{ALL}$ whether TKI post-treatment can compensate for MRD positivity before SCT. Nevertheless, in one randomized and several confirmatory studies, it has been convincingly demonstrated that a TKI treatment post-SCT is of benefit, even in patients who are MRD-negative after SCT. The TKI treatment, mostly with Imatinib, but also other TKIs, improved the outcome.
Another question concerns duration of the TKI treatment. Different options are suggested for the following therapeutic regimens: (1) until bcr-abl-negativity for 2-3 time points; (2) for 2.5 years as maintenance therapy in B-lineage ALL, or forever (a discussed item).

\section{$\mathrm{Ph}+\mathrm{ALL}$ in the era of TKI}

Ph+ ALL adult studies have demonstrated a substantial advantage for SCT in CR1 with an overall survival of $60-70 \%$. In one childhood study, intensive chemotherapy + TKI was sufficient to achieve a similar cure rate compared to a cohort with sibling- or unrelated donor transplant [11]. However, it has to be considered that Ph+ ALL in childhood is slightly different from adults, since many more additional cytogenetic aberrations are present in adult Ph+ALL. Some studies in adults, particularly with Dasatinib, currently explore whether a reasonable cure rate can be achieved without SCT. It seems, however, that the fraction of adult $\mathrm{Ph}+\mathrm{ALL}$ patients without a SCT is $\sim 30-40 \%$, all the other patients in these studies were later transplanted in cases of becoming bcr-abl-positive, or relapse, or in second CR. Thus, a randomized study is required in adult ALL in order to learn whether SCT is still needed in bcr/abl-negative patients in CR1.

Moreover, there is a newly discovered subtype, BCR-ABLlike ALL. For these cases, either a TKI, or a JAK2 inhibitor is indicated, depending on genetic aberrations [10].

For the newly discovered early T cell precursor (ETP) ALL, there are no new drugs proposed, except of Nelarabine evaluation, and those patients are candidates for allo-SCT in CR1, since they have a poor prognosis.

\section{Immunotherapeutic approaches in ALL}

Several surface antigens, representing the differentiation steps in B-lineage ALL, express antigens which could be targeted by antibodies. The available drugs include monoclonal anti-CD20 antibody (Rituximab), anti-CD22 (Inotuzumab Ozogamicin, IO), the bispecific CD3/CD19-directed antibody (Blinatumomab), or Chimeric Antigen Receptor modified T (CART) cells, directed against CD19 (Table 2).

The results with Rituximab are most convincing in adult Burkitt leukemia/lymphoma, where CD20-expression is $>90 \%$. Addition of Rituximab to intensive chemotherapy has resulted in a survival rate of $>80 \%$ [8]. CD20 is also positive in $\sim 40 \%$ of cells in common/pre-B ALL . When referring to GMALL study 07/2003, the Rituximab addition (day -1 , $375 \mathrm{mg} / \mathrm{m}^{2}$ for eight administrations) has further improved the outcomes of standard-risk patients, by about $15 \%$, to $\sim 70 \%$. The reason is a faster and higher MRD-negativity which is translated to increased disease-free survival. The question remains open, if Rituximab addition is also of benefit in high-risk patients, being candidates for a SCT in CR1.

Anti-CD22 antibody has been studied in relapsed/refractory ALL with a good CR rate, whereby a high percentage of those 
patients achieved a molecular remission [9]. Interestingly, this medication has been also piloted in a small study with elderly patients where the antibody was added to a reduced chemotherapy (Mini-HyperCVAD), yielding promising results. However, the follow-up in this trial was extremely short.

Blinatumomab is a novel bispecific construct that reacts simultaneously with normal CD3 T cells and CD19 ALL cells, creating a tight intercellular connection followed by T cellmediated cytotoxicity directed against CD19 blast cells (BiTE mechanism). An appropriate Phase 2 study was carried out in pre-B ALL patients being in hematological CR, but with molecular failure or molecular relapse after $\geq 3$ cycles of chemotherapy $(n=21)$. The endpoints included a complete molecular response (CMR), time to hematologic relapse, as well as incidence and severity of adverse events [12]. As a result, long-term remissions were achieved in some patients without SCT or any other treatment [13]. Very promising studies were performed with Blinatunomab in refractory/relapsed, or MRD-positive ALL patients. In heavily pre-treated cases, MRD was again chosen as primary endpoint, i.e., conversion from MRD positivity to MRD negativity $\leq 10^{-4}$ is clearly defined and measurable within weeks to months [6].

A novel option represents chimeric antigen receptor-modified $\mathrm{T}$ cells (CART), autologous $\mathrm{T}$ cells expressing a CD19-specific CD28/CD3 , dual-signaling, second-generation chimeric antigen receptor (CAR) termed as $19-28 \mathrm{z}$. The CD19-targeted $\mathrm{T}$ cells rapidly induce molecular remissions in adults with chemotherapy-refractory ALL [3].

\section{Conclusions}

Evaluation of minimal residual disease is a new parameter for treatment stratification. The conversion of MRD-positivity to MRD-negativity is also a new endpoint for studies.
Targeted therapy with TKIs, either first-generation drug (Imatinib), or second-generation agents (Dasatinib/Nilotinib), has substantially improved the outcome for adult $\mathrm{Ph}+$ ALL patients, eventually, by increased molecular remission rates and substantial improvement of survival to $60-70 \%$ after SCT.

Maintenance therapy with TKI is recommended after SCT, whereby its optimal duration is so far not known.

Nearly all $\mathrm{Ph}+/ \mathrm{bcr}-\mathrm{abl}+$ patients relapsing after chemo or SCT have specific mutations of the fusion gene, in particular, T351I. Such pharmaceutical products as the new third-generation TKI, Ponatinib, or other substances have to be explored, aiming to overcome drug resistance caused by such mutations.

Immunotherapeutic approaches offer new treatment options, required especially in adult ALL. Anti-CD20 Rituximab, as well as anti-CD22 Inotuzumab Ozogamicin, have been successfully explored in refractory/relapsed ALL, MRD-positive clinical situations, and also in cases of de novo treatment.

A new approach is to activate the patients' own T-cells to be directed against the targeted leukemic blast cells. Blinatumomab, a bispecific antibody, has shown its efficiency in MRD-positive patients, refractory/relapsed disease, and in ongoing studies concerning de novo induction/consolidation therapy.

A novel option concerns potential treatment with Chimeric Antigen Receptor (CAR)- modified T cells, where autologous T-cells against CD19-bearing leukemic cells could be generated. The results are promising, although small groups of patients, short follow-up terms, and considerable treatment-associated toxicity still leave many questions open.

\begin{tabular}{|c|c|c|c|c|}
\hline \multirow{2}{*}{$\begin{array}{l}\text { Surface } \\
\text { antigen }\end{array}$} & \multirow[t]{2}{*}{ All Subtype } & \multicolumn{2}{|c|}{ Expression $>20 \%$ of LBC } & \multirow[t]{2}{*}{ Monoclonal Antibody } \\
\hline & & Thiel $^{\star}$ N 584 & Raponi N 516* & \\
\hline CD20 & $\begin{array}{l}\text { B-precursor } \\
\text { Mature B-ALL }\end{array}$ & $\begin{array}{l}41 \% \\
86 \%\end{array}$ & $\begin{array}{l}22-30 \% \\
100 \%\end{array}$ & Rituximab \\
\hline CD52 & $\begin{array}{l}\text { B-precursor } \\
\text { T-precursor }\end{array}$ & $\begin{array}{l}79 \% \\
77 \%\end{array}$ & & Alemtuzumab \\
\hline CD22 & $\begin{array}{l}\text { B-precursor } \\
\text { Mature B-ALL }\end{array}$ & $\begin{array}{l}60-85 \% \\
69 \%\end{array}$ & $\begin{array}{l}93-96 \% \\
100 \%\end{array}$ & $\begin{array}{l}\text { Epratuzumab } \\
\text { Inotuzumab Ozogamicin }\end{array}$ \\
\hline CD33 & $\begin{array}{l}\text { B-precursor } \\
\text { T-precursor } \\
\text { Ph+ ALL }\end{array}$ & $\begin{array}{l}23 \% \\
9 \% \\
40 \%\end{array}$ & $17-26 \%$ & $\begin{array}{l}\text { Gemtuzumab* } \\
\text { Ozogamicin }\end{array}$ \\
\hline CD19 & $\begin{array}{l}\text { B-precursor } \\
\text { Mature B-ALL }\end{array}$ & $\begin{array}{l}95 \% \\
94 \%\end{array}$ & $\begin{array}{l}100 \% \\
100 \%\end{array}$ & Blinatumomab \\
\hline
\end{tabular}

*Data from the German Multicentre Study Group for Adult ALL (GMALL) central Immunophenotyping, E. Thiel, S. Schwartz, Berlin, Germany (personal communication).

${ }^{* *}$ Raponi et al. Leukemiaßlymphoma. 201152 (6): 1098-17.

Table 1. Expression of surface antigens for potential antibody therapy in ALL 


\section{References}

1. Bassan R, Spinelli O, Oldani E, Intermesoli T, Tosi M, Peruta B, Rossi G, Borlenghi E, Pogliani EM, Terruzzi E, Fabris $P$, Cassibba V, Lambertenghi-Deliliers G, Cortelezzi A, Bosi A, Gianfaldoni G, Ciceri F, Bernardi M, Gallamini A, Mattei D, Di Bona E, Romani C, Scattolin AM, Barbui T, Rambaldi A. Improved risk classification for risk-specific therapy based on the molecular study of minimal residual disease (MRD) in adult acute lymphoblastic leukemia (ALL). Blood. 2009; 113(18): 4153-62.

2. Bassan R, Hoelzer D. Modern therapy of acute lymphoblastic leukemia. J Clin Oncol. 2011; 29(5): 532-43.

3. Brentjens RJ, Davila ML, Riviere I, Park J, Wang X, Cowell LG, Bartido S, Stefanski J, Taylor C, Olszewska M, Borquez-Ojeda O, Qu J, Wasielewska T, He Q, Bernal Y, Rijo IV, Hedvat C, Kobos R, Curran K, Steinherz P, Jurcic J, Rosenblat T, Maslak P, Frattini M, Sadelain M. CD19-targeted $T$ cells rapidly induce molecular remissions in adults with chemotherapy-refractory acute lymphoblastic leukemia. Sci Transl Med. 2013; 5(177):177ra38.

4. Brüggemann M1, Schrauder A, Raff $T$, Pfeifer $H$, Dworzak M, Ottmann OG, Asnafi V, Baruchel A, Bassan R, Benoit Y, Biondi A, Cavé H, Dombret H, Fielding AK, Foà R, Gökbuget N, Goldstone AH, Goulden N, Henze G, Hoelzer D, Janka-Schaub GE, Macintyre EA, Pieters R, Rambaldi A, Ribera JM, Schmiegelow K, Spinelli O, Stary J, von Stackelberg A, Kneba M, Schrappe M, van Dongen JJ; European Working Group for Adult Acute Lymphoblastic Leukemia (EWALL); International Berlin-Frankfurt-Münster Study Group (I-BFM-SG). Standardized MRD quantification in European ALL trials: proceedings of the Second International Symposium on MRD assessment in Kiel, Germany, 18-20 September 2008. Leukemia. 2010; 24(3): 521-35.

5. Gökbuget N, Basara N, Baurmann H, Beck J, Brüggemann M, Diedrich H, Güldenzoph B, Hartung G, Horst HA, Hüttmann A, Kobbe G, Naumann R, Ratei R, Reichle A, Serve H, Stelljes M, Viardot A, Wattad M, Hoelzer D. High single-drug activity of nelarabine in relapsed T-lymphoblastic leukemia/lymphoma offers curative option with subsequent stem cell transplantation. Blood. 2011; 118(13): 35043511.

6. Handgretinger R, Zugmaier G, Henze G, Kreyenberg H, Lang P, von Stackelberg A. Complete remission after blinatumomab-induced donor T-cell activation in three pediatric patients with post-transplant relapsed acute lymphoblastic leukemia. Leukemia. 2011; 25(1): 181-184.

7. Hoelzer D, Gökbuget N. Chemoimmunotherapy in acute lymphoblastic leukemia. Blood Rev. 2012; 26(1): 25-32.

8. Hoelzer D, Walewski J, Döhner H, Viardot A, Hiddemann W, Spiekermann K, Serve H, Dührsen U, Hüttmann A, Thi el E, Dengler J, Kneba M, Schaich M, Schmidt-Wolf IG, Beck J, Hertenstein B, Reichle A, Domanska-Czyz K, Fietkau R, Horst HA, Rieder H, Schwartz S, Burmeister T, Gökbuget N; German Multicenter Study Group for Adult Acute
Lymphoblastic Leukemia. Improved outcome of adult Burkitt lymphoma/leukemia with rituximab and chemotherapy: report of a large prospective multicenter trial. Blood 2014; 124 (26): 3870-9.

9. Kantarjian H, Thomas D, Jorgensen J, Jabbour E, Kebriaei P, Rytting M, York S, Ravandi F, Kwari M, Faderl S, Rios MB, Cortes J, Fayad L, Tarnai R, Wang SA, Champlin R, Advani A, O’Brien S. Inotuzumab ozogamicin, an anti-CD22-calecheamicin conjugate, for refractory and relapsed acute lymphocytic leukaemia: a phase 2 study. Lancet Oncol 2012; 13(4): 403-11.

10. Roberts KG, Li Y, Payne-Turner D, Harvey RC, Yang YL, Pei D, McCastlain K, Ding L, Lu C, Song G, Ma J, Becksfort J, Rusch M, Chen SC, Easton J, Cheng J, Boggs K, Santiago-Morales N, Iacobucci I, Fulton RS, Wen J, Valentine M, Cheng C, Paugh SW, Devidas M, Chen IM, Reshmi S, Smith A, Hedlund E, Gupta P, Nagahawatte P, Wu G, Chen X, Yergeau D, Vadodaria B, Mulder H, Winick NJ, Larsen EC, Carroll WL, Heerema NA, Carroll AJ, Grayson G, Tasian SK, Moore AS, Keller F, Frei-Jones M, Whitlock JA, Raetz EA, White DL, Hughes TP, Guidry Auvil JM, Smith MA, Marcucci G, Bloomfield CD, Mrózek K, Kohlschmidt J, Stock W, Kornblau SM, Konopleva M, Paietta E, Pui CH, Jeha S, Relling MV, Evans WE, Gerhard DS, Gastier-Foster JM, Mardis E, Wilson RK, Loh ML, Downing JR, Hunger SP, Willman CL, Zhang J, Mullighan CG. Targetable kinase-activating lesions in Ph-like acute lymphoblastic leukemia. N Engl J Med 2014; 371(11): 1005-15.

11. Schultz KR, Carroll A, Heerema NA, Bowman WP, Aledo A, Slayton WB, Sather H, Devidas M, Zheng HW, Davies SM, Gaynon PS, Trigg M, Rutledge R, Jorstad D, Winick N, Borowitz MJ, Hunger SP, Carroll WL, Camitta B. Children's Oncology Group. Long-term follow-up of imatinib in pediatric Philadelphia chromosome-positive acute lymphoblastic leukemia: Children's Oncology Group study AALL0031. Leukemia 2014; 28(7): 1467-71.

12. Topp MS, Kufer P, Gökbuget N, Goebeler M, Klinger M, Neumann S, Horst HA, Raff T, Viardot A, Schmid M, Stelljes M, Schaich M, Degenhard E, Köhne-Volland R, Brüggemann M, Ottmann O, Pfeifer H, Burmeister T, Nagorsen D, Schmidt M, Lutterbuese R, Reinhardt C, Baeuerle PA, Kneba M, Einsele H, Riethmüller G, Hoelzer D, Zugmaier G, Bargou RC. Targeted therapy with the T-cell-engaging antibody blinatumomab of chemotherapy-refractory minimal residual disease in B-lineage acute lymphoblastic leukemia patients results in high response rate and prolonged leukemia-free survival. J Clin Oncol 2011; 29(18): 2493-8.

13. Topp MS, Gökbuget N, Zugmaier G, Degenhard E, Goebeler ME, Klinger M, Neumann SA, Horst HA, Raff T, Viardot A, Stelljes M, Schaich M, Köhne-Volland R, Brüggemann M, Ottmann OG, Burmeister T, Baeuerle PA, Nagorsen D, Schmidt M, Einsele H, Riethmüller G, Kneba M, Hoelzer D, Kufer P, Bargou RC. Long-term follow-up of hematologic relapse-free survival in a phase 2 study of blinatumomab in patients with MRD in B-lineage ALL. Blood 2012; 120(26): 5185-7. 